\author{
Ольга Горецька, \\ викладач, \\ Івано-Франківський фаховий коледж \\ Прикарпатського національного \\ університету імені Василя Стефаника \\ (м. Івано-Франківськ, Україна)
}

\section{Olha Horetska,}

teacher,

Ivano-Frankivsk professional college

of Vasyl Stefanyk Precarpathian National University

(Ivano-Frankivsk, Ukraine)

olha.horetska@pnu.edu.ua

\section{Марія Оліяр,}

доктор педагогічних наук, професор,

завідувач кафедри педагогіки початкової освіти,

Прикарпатський національний університет

імені Василя Стефаника»

(м. Івано-Франківськ, Україна)

\section{Mariia Oliiar,}

Doctor of Pedagogical Sciences, Professor,

Head of Department of Pedagogy of Primary Education,

Vasyl Stefanyk Precarpathian National University

(Ivano-Frankivsk, Ukraine)

oliyar27@gmail.com

ORCID ID 0000-0002-1592-1780

Удк: 378:373.5.011

\title{
НАУКОВІ ЗАСАДИ ПРОЦЕСУ ФОРМУВАННЯ КРИТИЧНОГО МИСЛЕННЯ МАЙУТНІХ УЧИТЕЛІВ ПОЧАТКОВОЇ ШКОЛИ
}

Анотація. Мета статті - аналіз наукових засад процесу формування критичного мислення майбутніх учителів початкової школи. Завдання дослідження: проаналізувати наукові трактування змісту поняття «критичне мислення педагога»; виявити наукові підходи до розроблення технологій формування критичного мислення студентів педагогічних ЗВО.

У статті розкрито актуальність проблеми формування критичного мислення майбутніх фахівців у період інтенсивних соціально-економічних змін в Україні. Адже лише критично мислячий педагог здатний до творчої інноваційної діяльності. Учитель, який не володіє критичним мисленням, не може навчити критично мислити своїх учнів.

Автор статті зазначає, що в науковій літературі існує чимало трактувань поняття «критичне мислення». Воно розглядається насамперед як один із аспектів рефлексії. Критичне мислення обов'язково передбачає як позитивне, так і негативне оцінювання мислительного процесу і його результатів. Характерними ознаками критичного мислення учені називають його системність та здатність до узагальнень. У зв'язку з цим актуальним є оволодіння низкою прийомів інтелектуальної діяльності. Учені розглядають критичне мислення нерозривно з творчим мисленням.

Автор підкреслює, що розвиток критичності мислення - складне завдання. Ця якість розвивається в процесі вирішення проблемних педагогічних ситуацій. Вона охоплює формування у майбутніх педагогів системи знань про суть цього явища (мислення, рефлексія, педагогічне і критичне мислення), оволодіння засобами і способами формування критичності мислення (методи, прийоми, форми, засоби, технології).

У статті визначено низку методологічних підходів до розв'язання проблеми формування критичного мислення студентів. Особистісно-прагматичний підхід реалізується в індивідуальних і групових формах навчання студентів, в діалогічній діяльності, в ігровій взаємодії. Ситуативний підхід передбачає формування кейсів проблемних педагогічних ситуацій, їх моделювання, аналіз та розв'язання. Діяльнісний підхід включає навчання студентів планування (визначення мети, змісту, форм, методів) та реалізації педагогічної діяльності (регулювання, контроль, критичний самоаналіз і самооцінка досягнутих результатів).

На основі аналізу праць учених визначено найважливіші характеристики технології формування критичного мислення студентів: рівноправність суб'єктів навчання; роль викладача як фасилітатора освітнього процесу; створення 
освітнього середовища, де панує атмосфера пошуку й відкритості, природної співпраці та комунікації; віра в сили студента, підтримка його активної позиції в навчанні тощо.

Ключові слова: Педагогічне мислення, критичне мислення, майбутній учитель початкової школи, особистіснопрагматичний підхід, ситуативний підхід, діяльнісний підхід, технологія формування критичного мислення.

\section{SCIENTIFIC FUNDAMENTALS OF THE PROCESS OF FORMATION OF CRITICAL THINKING OF FUTURE PRIMARY SCHOOL TEACHERS}

Abstract. The purpose of the article is to analyze the scientific foundations of the process of forming critical thinking of future primary school teachers. Objectives of the study: to analyze scientific interpretations of the content of the concept of "critical thinking of the teacher»; to identify scientific approaches to the development of technologies for the formation of critical thinking of students of pedagogical free economic zones.

The urgency of the problem of formation of critical thinking of future specialists in the period of intensive social and economic changes in Ukraine is revealed in the article. Only a critical educator is capable of creative innovation. A teacher who does not have critical thinking cannot teach his students to think critically.

The author of the article notes that in the scientific literature there are many interpretations of the concept of «critical thinking». It is seen primarily as one aspect of reflection. Critical thinking necessarily involves both positive and negative evaluation of the thought process and its results. Characteristic features of critical thinking, scientists call its systematization and ability to generalize. In this regard, it is important to master a number of techniques of intellectual activity. Scientists consider critical thinking inseparable from creative thinking.

The author notes that the development of critical thinking is a difficult task. This quality develops in the process of solving problematic pedagogical situations. It covers the formation of future teachers'; system of knowledge about the essence of this phenomenon (thinking, reflection, pedagogical and critical thinking), mastering the means and methods of forming critical thinking (methods, techniques, forms, tools, technologies).

The author of the article identified a number of methodological approaches to solving the problem of forming students'; critical thinking. The personal- pragmatic approach is realized in individual and group forms of training of students, in dialogic activity, in game interaction. The situational approach involves the formation of cases of problematic pedagogical situations, their modeling, analysis and solution. The activity approach includes teaching students to plan (determine the purpose, content, forms, methods) and implementation of pedagogical activities (regulation, control, critical self-analysis and self-assessment of achieved results).

Based on the analysis of the works of scientists, the author identifies the most important characteristics of the technology of formation of critical thinking of students: equality of subjects of study; the role of the teacher as a facilitator of the educational process; creating an educational environment where there is an atmosphere of search and openness, natural cooperation and communication; belief in the strength of the student, support for his active position in learning, etc.

Keywords: Pedagogical thinking, critical thinking, future primary school teacher, personal-pragmatic approach, situational approach, activity approach, technology of critical thinking formation.

\section{вСТУП}

Постановка проблеми. Сучасний період становлення Української держави характеризується бурхливим розвитком інформаційного простору на базі новітніх технологій, міжультурною інтеграцією, посиленням взаємодії з іншими державами як у матеріальній, так і в духовній сферах, у тому числі й у галузі освіти. у цих умовах учитель загальнооосвітньої школи не лише сам повинен орієнтуватися в потоці інформації, багатовимірному педагогічному середовищі, але й розвивати в учнів здатність до вирішення різноманітних проблем сучасності. Не випадково суспільство відводить особистості вчителя провідну роль у 21 столітті. Сучасному педагогові доводиться не лише аналізувати та використовувати педагогічний досвід, але й мислити на перспективу для того, щоб освітній процес відповідав запитам суспільства. За цих умов формування критичного педагогічного мислення майбутнього вчителя є одним із можливих способів розв'язання освітніх проблем.

Учені стверджують, що «критичне мислення особливо актуальне в часи інтенсивних соціальних змін, коли, щоб діяти ефективно й успішно, необхідно постійно пристосовуватися до нових політичних та економічних реалій, коли доводиться розв'язувати проблеми, значну частину яких неможливо передбачити заздалегідь. Тому для України й української освіти підготовка молоді, здатної мислити критично, - життєво необхідне завдання. Лише критично мисляча людина здатна до продуктивної творчості та інновацій, спрямованих на позитивну діяльність задля корисного внеску в суспільне благо. Однак, учитель, який сам не володіє критичним мисленням, не може навчити критично мислити своїх учнів» (Астаф'єва М., Прошкін В., Радченко С., 2018, с. 104-105).

Аналіз наукових досліджень і публікацій. Проблемі розвитку критичного мислення присвячено чимало сучасних наукових досліджень вітчизняних та зарубіжних авторів (М. Астаф'єва, І. Горохова, Дж. Дьюї, Л.Занков, Л. Києнко-Романюк, В. Кремень, А. Кроуфорд, Н. Максименко, О. Пометун, В. Прошкін, О. Пометун, С. Радченко, Дж. Л. Стіл, І. Сущенко, С. Терно, О. Тягло, А. Фішер, О. Чуба та ін.). Водночас проблема розвитку критичного мислення майбутніх учителів початкової школи та їх підготовки до відповідної роботи з учнями залишається недостатньо дослідженою.

МЕТА I ЗАВДАННЯ ДОСЛІДЖЕННЯ

Мета дослідження - аналіз наукових засад процесу формування критичного мислення майбутніх учителів початкової школи.

Завдання дослідження:

1) проаналізувати наукові трактування змісту поняття «критичне мислення педагога»;

2) виявити основні наукові підходи до розроблення технологій формування критичного мислення студентів педагогічних ЗВО. 


\section{МЕТОДИ ДОСЛІДЖЕННЯ}

Системний та порівняльний аналіз теоретико-методологічної, науково-методичної, психолого-педагогічної літератури; узагальнення теоретичних даних; вивчення досвіду впровадження інноваційних технологій в освітній процес ЗВО.

\section{РЕЗУЛЬТАТИ ДОСЛІДЖЕННЯ}

Одним із провідних завдань професійної підготовки майбутніх учителів початкової школи, від якого залежить успішність удосконалення системи сучасної освіти в Україні, $€$ формування педагогічного мислення, що характеризується високим рівнем аналізу педагогічних ситуацій, синтезу, прогнозування освітнього процесу, рефлексії і дозволяє вчителеві відповідно організовувати свої дії з метою цілеспрямованого вирішення завдань навчання й виховання учнів. На думку відомого психолога

С. Рубінштейна, «мислення є процесом саме тому, що кожен крок мислення, будучи обумовлений об'єктом, по-новому розкриває об'єкт, а зміна цього останнього в свою чергу необхідно обумовлює новий хід мислення» (Рубинштейн С. Л., 1958, с. 136). Педагогічне мислення як різновид професійного мислення і антипод догматизму є специфічною розумовою діяльністю, для якої характерна цілеспрямованість, широта й глибина розуму, гнучкість, самостійність, об'єктивність, науковість, логічність, наполегливість, послідовність у досягненні мети, відкритість до нового, готовність до самокорекції. При цьому відбувається відображення в свідомості педагога сутності та особливостей процесів і явищ педагогічної дійсності, суперечностей, що обумовлюють постановку нових завдань відповідно до соціальних цілей виховання й освіти, суб'єктивне конструювання педагогічного процесу шляхом розроблення планів і проєктів вирішення цих завдань, регуляцію процесу здійснення планів, оцінку отриманих результатів.

Розуміння, аналіз, порівняння, прогнозування, моделювання педагогічних явищ тісно пов'язане із практичним застосуванням наукових знань, використанням сучасних педагогічних технологій, цінісно-етичною спрямованістю педагогічного мислення сучасного вчителя та його креативністю. Чимало учених (М. Каган, О. Савченко, В. Сухомлинський, В. Кремень, К. Ушинський та ін.) наголошують на тому, що специфіка педагогічного мислення полягає саме в його конструктивно-перетворювальній творчій функції, що споріднює його 3 мистецтвом. Найбільш яскраво це виявляється в процесі вирішення педагогічних проблемних ситуацій, які вимагають вибору й застосування методів, прийомів, засобів, що відповідають цим ситуаціям, конструювання нових способів педагогічного впливу на учнів і на освітній процес у цілому. «Де немає питання, чи проблеми для вирішення, чи де немає трудності, яку треба подолати, потік думок іде навмання ... Проблема визначає мету думки, а мета контролює процес мислення», - писав Д. Дьюї (Дьюи Д., 1997, с. 10).

Це зумовлює необхідність формування критичного мислення майбутніх учителів як складника їхнього педагогічного мислення. В умовах соціально-економічних змін, що відбуваються в нашій країні, впровадження Концепції нової української школи перед педагогічними ЗВО питання про якість підготовки майбутніх учителів до продуктивної педагогічної діяльності постає особливо гостро. Сучасне розуміння особистісно орієнтованої освіти як процесу становлення людини передбачає, що система вищої професійної освіти покликана під час навчання допомогти студентам вибудувати власний світ цінностей, знань, оволодіти творчими способами вирішення наукових і життєвих проблем, відкрити рефлексивний світ власного «я» і навчитися керувати ним. У період навчання студенти навчаються самостійно здобувати знання, оволодівати вміннями сприймати нову інформацію і осмислювати її, порівнювати різні точки зору. Вирішення цих завдань вимагає формування критичного мислення майбутнього вчителя, без якого не можна досягти ні педагогічної компетентності, ні творчої активності. У західній системі критичне мислення впродовж кількох останніх десятиліть набуло значення технологічної методології, яка застосовується в різних сферах інтелектуальної діяльності людини. Це сприяло тому, що в навчальних планах міжнародних освітніх центрів з'явилася нова дисципліна «Критичне мислення» (Горохова І. В., 2016).

У науковій літературі існує чимало трактувань критичного мислення. Як зазначає Н. Максименко, «сучасному суспільству, а значить, і сучасній освіті, необхідна вільна, творча особистість, що володіє певними якостями мислення. Свобода мислення має на увазі критичну її спрямованість, орієнтовану на творчу і конструктивну діяльність, тому якісною характеристикою мислення вільної особистості є критичне мислення». Отже, робить висновок науковець, «провідним завданням педагогічної освіти є забезпечення не тільки високого професійного рівня майбутніх учителів, але й зростання їхнього інтелектуального потенціалу, формування здатності до критичного аналізу та всебічної обробки інформації, спроможності своєчасно вносити необхідні корективи у професійну діяльність, уміння приймати рішення, робити правильні висновки» (Максименко Н., 2016, с. 201).

О. Пометун зазначає, що критичне мислення - це здатність людини усвідомлювати власну позицію з того чи іншого питання, вміння продукувати нові ідеї, аналізувати події і оцінювати їх, приймати ретельно обдумані, зважені рішення (Пометун О. І., 2010).

Л. Києнко-Романюк у своєму дисертаційному дослідженні наводить деталізовану класифікацію провідних ознак критичного мислення: мотиваційна компонента (ставлення до навчання, рівень потягу до самоствердження, усвідомлення життєвої цінності інформації, бажання перевірити свої можливості, схильність до змагання); змістова компонента (достатній рівень первинних знань, знання про прийоми аналітично-ментальних розумових дій, раціональні й ефективні методи навчання і самонавчання, самоконтролю та самокорекції діяльності й мислення, оцінювання значення отриманих знань); інтелектуально-процесуальна компонента (спроможність «здійснювати процес», володіння ефективними прийомами для вирішення завдань); емоційно-вольова компонента (наполегливість, воля, цілеспрямованість, вміння зберігати позитивний емоційний стан під час пошуків шляхів вирішення проблеми). Їх інтегральними характеристиками, зазначає автор, виступають знання, інтереси, потреби, морально-етичні цінності та система взаємин, що виявляються через установки, поведінку, відносини «викладач (тренер) - студент» на різних рівнях взаємодії (Києнко-Романюк Л. А., 2007, с. 10). 
У процесі виникнення певних освітніх завдань вчитель осмислює й оцінює об'єктивні умови, в яких ці завдання будуть вирішуватися. Результатом такої розумової діяльності стає виникнення задуму майбутньої діяльності. Наступним етапом є процес відбору набутих знань, умінь і навичок, а також методів, прийомів і засобів вирішення завдань. Критичний їх аналіз може привести до виникнення нового оригінального способу, прийому або засобу. Наступний крок - це вибір оптимального з можливих вирішень поставленого завдання шляхом аналізу, оцінки різних варіантів. На етапі реалізації задуму здійснюється корегування способів вирішення завдання. Кінцевим етапом є аналіз результатів, їх критична оцінка з метою подальшого впровадження цього способу вирішення в інших ситуаціях і прогнозування освітньої діяльності педагога. На всіх перечислених етапах необхідне їх критичне осмислення.

Критичне мислення майбутніх педагогів розглядається насамперед як один із аспектів рефлексії - якості, що відіграє найважливішу роль у процесі вибору, регуляції та оцінювання власних педагогічних дій. Рефлексуючи, вчитель використовує теоретичні методи пізнання з метою аналізу знання, його структури та змісту, контролює свої дії, в тому числі й розумові, відстежує логіку розгортання власної думки, усвідомлює суперечності, які є причиною руху думки та конкретних дій, здійснює діалектичний підхід до аналізу ситуації, враховуючи позиції різних учасників освітнього процесу, тощо.

Крім цього, критичне мислення обов'язково передбачає як позитивне, так і негативне оцінювання в тому чи іншому вигляді. Це оцінювання і самого мислительного процесу, ходу міркувань, які враховувалися при прийнятті рішення, і результату - правильності прийнятого рішення, вдалих або невдалих дій педагога.

Окрім зазначеного, вчені визначають критичне мислення як «здатність продукувати ідеї, визначати стратегічні питання та їх вирішувати, знаходити переконливу аргументацію, брати на себе відповідальність, відстоювати власну позицію та корегувати її під аргументованим впливом опонентів» (Астаф'єва М., Прошкін В., Радченко С., 2018, с. 102-103). Однією з характерних ознак критичного мислення вчені називають його системність, а також здатність до узагальнень як основи абстрактного мислення: «мислити критично означає бути здатним мислити абстрактно. Жодне дослідження неможливе без абстрактного мислення; без нього не буде якісного мислення конкретного, образного» (Астаф'єва М., Прошкін В., Радченко С., 2018, с. 111). У зв'язку з цим актуальним є оволодіння прийомами усвідомлення проблеми, обрання несуперечливих доказів; знаходження контраргументів; обґрунтування; обрання однієї із багатьох альтернатив; усвідомлення обмежень, що накладаються на висновок, тощо (Терно С. О., 2012; Чуба О., 2013).

Критичне мислення продуктивне тоді, коли воно пов'язане з творчим мисленням. «Мислення - це певна форма життя особистості, яка реалізується за допомогою міркувань і роздумів, а також створює умови для знайомства цієї людини з іншими. Водночас це може бути й форма соціального життя, що реалізується через творчість особистості» (Критичне мислення, 2017, с. 4-5). Лише за наявності творчого підходу педагог створює принципово нові елементи освітнього процесу або оригінальні способи вирішення освітніх задач, які підлягають тестуванню в процесі критичного осмислення. Творче мислення спрямоване на створення новоих ідей, а критичне виявляє їх недоліки. Творчість буде малопродуктивною, якщо її не можна критично перевірити і визначити вартісність отриманого продукту. Стимулом творчої діяльності є проблемна ситуація, яку неможливо вирішити традиційними способами.

Розвиток критичності мислення - складне комплексне завдання, що вимагає від майбутнього фахівця високого рівня знань, культури, самосвідомості. Критичність заснована на розгалуженій системі властивостей, кожна 3 яких є її складником, хоча може мати й відносну самостійність. Це гнучкість мислення, що дає змогу студентові в процесі розв'язання педагогічного завдання не зупинятися на якомусь одному варіанті рішення, а з урахуванням думки товаришів по групі змінювати його залежно від умов педагогічної дійсності, які складаються в тій чи іншій проблемній ситуації. Послідовність думки - це вміння дотримуватися строгого логічного порядку в розгляді того чи іншого питання. Завдяки самостійності мислення педагог може приймати рішення, на які неможливо вплинути ззовні, аналізувати свої рішення, бачити в них як сильні, так і слабкі сторони і на цій підставі коригувати процес розв'язання проблеми. Критичне мислення вчителя є відкритим типом мислення, що виявляється у визнанні вчителем неоднозначності, різноманітності, неоднорідності педагогічних фактів і явищ. Це далеко не повний перелік якостей критичного мислення майбутніх педагогів, які необхідно сформувати.

Розкриваючи зміст технології формування критичного мислення студентів, Н. Максименко наголошує на таких її важливих рисах: 1) суб'єкти навчання рівноправні між собою; 2) студенти відкрито обговорюють те чи інше питання, дізнаються не тільки про ідеї одне одного, а й про особистий хід міркувань - аргументування ідей; 3) викладач $€$ фасилітатором, він лише консультує, моделює процес мислення, підтримує студентів, демонструє, як можна мислити критично, формулює ідеї обґрунтованого мислення, заохочує поважати різні точки зору, ставить під сумнів висновки та знання як свої власні, так і інших і заохочує студентів до такої ж критичної роботи, дає поради більше з метою корекції їхньої діяльності, ніж її критики чи оцінки; 4) існує атмосфера пошуку й відкритості; 5) сворюється освітнє середовище, де студенти почуваються захищеними та вільними; 6) освітній простір побудовано таким чином, щоб зробити легкою та природною співпрацю і комунікацію; 7) робота з розвитку критичного мислення має проводитися не тільки на занятті, а й при виконанні самостійної роботи чи індивідуального завдання та передбачати постійний пошук, розумове напруження майбутніх фахівців; 8) очікування ідей, висловлення думок у будь-якій формі, ї діапазон може бути необмеженим, а гіпотези можуть бути різноманітними, нетривіальними;

9) цінування думок інших, усвідомлення, що для знаходження оптимального розв'язання проблеми дуже важливо вислухати всі думки зацікавлених людей, щоб мати можливість остаточно сформулювати власну думку, яка може бути скоригована в колективній діяльності; 10) віра в сили студента, підтримка його активної позиції в навчанні для досягнення мети справжнього задоволення від здобуття знань, що стимулює прагнення мислити нестандартно, критично. За таких умов, вважає автор, майбутні вчителі перетворюються на особистостей, здатних упродовж усього життя відкривати нові ідеї та інформацію і трансформувати її у практичні вміння й навички (Максименко Н., 
2016, с. 202-203). 3 цією ж метою пропонується інтегрувати в освітньому процесі сучасні інформаційні технології та активні форми і методи навчання (дискусія, проєктна діяльність, проблемні, дослідницькі методи тощо).

Процес формування критичного мислення майбутніх педагогів грунтується на сучасних методологічних підходах, а саме: особистісно-прагматичний підхід реалізується в діалогічній діяльності, в ігровій взаємодії, в індивідуальних і групових формах навчання студентів; ситуативний підхід передбачає формування кейсів проблемних педагогічних ситуацій, їх моделювання, аналіз та розв'язання; діяльнісний підхід включає навчання студентів планування (визначення мети, змісту, форм, методів) та реалізації педагогічної діяльності (регулювання, контроль, критичний самоаналіз і самооцінка досягнутих результатів).

\section{ВИСНОВКИ ТА ПЕРСПЕКТИВИ ПОДАЛЬШИХ ДОСЛІДЖЕНЬ}

Головним завданням сучасної вищої школи є виховання особистості, готової до життя у високотехнологічному конкурентному світі. У цих умовах володіння критичним мисленням вважається необхідним для фахівця будь-якої сфери, і насамперед для педагога. Критичне мислення зорієнтоване насамперед на активну участь у соціальній життєдіяльності, а також на вибудову та регулювання індивідуальної професійної і життєвої траєкторії. У найбільш узагальненому вигляді критичне мислення вчителя початкової школи - складна інтегративна якість, що являє собою здатність аналізувати інформацію з позиції логіки для того, щоб використовувати отримані результати у стандартних та нестандартних педагогічних ситуаціях, виробляти нові творчі підходи до організації освітнього процесу, приймати незалежні, аргументовані, продумані рішення. При цьому обрані когнітивні стратегії і техніки повинні бути обгрунтовані й ефективні для конкретної педагогічної ситуації чи типу професійної задачі. Технології формування критичного мислення майбутніх педагогів грунтуються на особистісно-прагматичному, ситуативному, діяльнісному підходах у професійній підготовці, інтеграції сучасних інформаційних технологій і активних форм та методів навчання.

\section{СПИСОК ВИКОРИСТАНИХ ДЖЕРЕЛ}

Астаф'єва М., Прошкін В., Радченко С. (2018). Формування критичного мислення майбутніх учителів математики засобами геометрії. Освітологічний дискурс, 1-2 (20-21), $100-115$.

Горохова І. В. (2016). Мовно-комунікативні практики формування критичного мислення в сучасних університетах США : дис. ... канд. філософ. наук : 09.00.10 «Філософія освіти», Київ.

Дьюи Д. (1997). Психология и педагогика мышления. Москва: Совершенство.

Києнко-Романюк Л. А. (2007). Розвиток критичного мислення студентської молоді як загально-педагогічна проблема : автореф. дис. ... канд. пед. наук. Київ.

Критичне мислення: освіта, творчість, цінності : монографія / за заг. ред. В. Г. Кременя (2017). Київ : Інститут обдарованої дитини НАПН України.

Максименко Н. (2016). Особливості формування критичного мислення у майбутніх учителів біології при вивченні курсу «Мікробіологія». Витоки педагогічної майстерності, 18, 201-206.

Пометун О. І. (2010). Основи критичного мислення : навчальний посібник для учнів старших класів загальноосвітньої школи / О. І. Пометун, Л. М. Пилипчатіна, І. М. Сущенко, І. О. Баранова. Тернопіль: Навчальна книга - Богдан.

Рубинштейн С. Л. (1958). О мышлении и путях его исследования. Москва : АН СССР

Терно С. О. (2012). Світ критичного мислення: образ та мімікрія. Історія в сучасній школі, 7-8, 27-39.

чуба О. (2013). Формування критичного мислення як психолого-педагогічна проблема сучасності. Педагогіка і психологія професійної освіти, 3, 202-208.

\section{REFERENCES}

Astafyeva, M., Proshkin, V., \& Radchenko, S. (2018). Formuvannya krytychnogo myslennya majbutnix uchyteliv matematyky zasobamy geometriyi [Formation of critical thinking of future teachers of mathematics by means of geometry]. Osvitologichnyj dyskurs, 1-2 (20-21), 100-115.

Goroxova, I. V. (2016). Movno-komunikaty`vni praktyky formuvannya

krytychnogo myslennya v suchasnyx universytetax SShA [Linguistic and communicative practices of formation critical thinking in modern universities USA]. dys. ... kand. filosof. nauk : 09.00.10 «Filosofiya osvity», Kyyiv.

Dyuy D. (1997). Psyxologyya y pedagogyka myshlenyya [Psychology and pedagogy of the mouse]. Moskva: Sovershenstvo.

Kyyenko-Romanyuk, L. A. (2007). Rozvytok krytychnogo myslennya studentskoyi molodi yak zagalno-pedagogichna problema [Development of student critical thinking youth as a general pedagogical problem]. Avtoref. dys. ... kand. ped. nauk. Kyyiv.

Krytychne myslennya: osvita, tvorchist, cinnosti : monografiya [Critical thinking: education, creativity, values: monograph] / za zag. red. V. G. Kremenya (2017). Kyyiv : Insty'tut obdarovanoyi dytyny NAPN Ukrayiny.

Maksymenko, N. (2016). Osoblyvosti formuvannya krytychnogo myslennya u majbutnix uchyteliv biologiyi pry vyvchenni kursu «Mikrobiologiya» [Features of the formation of critical thinking in future teachers of biology when studying the course "Microbiology"]. Vytoky pedagogichnoyi majsternosti, 18, 201-206.

Pometun, O. I. et al. (2010). Osnovy krytychnogo myslennya : navchalnyj posibnyk dlya uchniv starshyx klasiv zagalnoosvitnoyi shkoly [Fundamentals of critical thinking: a textbook for high school students]. Ternopil : Navchalna knyga - Bogdan.

Rubynshtejn, S. L. (1958). O myshlenyy y putyax ego yssledovanyya [About thinking and ways of its research]. Moskva : AN SSSR.

Terno, S. O. (2012). Svit krytychnogo mylennya: obraz ta mimikriya [The world of critical thinking: image and mimicry]. Istoriya v suchasnij shkoli, 7-8, 27-39.

Chuba, O. (2013). Formuvannya krytychnogo myslennya yak psyxologo-pedagogichna problema suchasnosti [Formation of critical thinking as a psychological and pedagogical the problem of modernity]. Pedagogika i psy`xologiya profesijnoyi osvity, 3, 202-208. 